\title{
IMPLEMENTASI METODE GRAPHIC RATING SCALE PADA SISTEM PENUNJANG KEPUTUSAN SELEKSI PENERIMAAN BANTUAN BERAS MISKIN (RASKIN) DI DESA MACCILE KABUPATEN SOPPENG
}

\author{
Ismail $^{1}$, Nursakti $^{2}$ \\ Sistem Informasi, STMIK Lamappapoleonro Soppeng \\ Email : ismailcom09@gmail.com ${ }^{1}$,nursaktibaharuddin@gmail.com²
}

\begin{abstract}
ABSTRAK
Program Bantuan Beras Miskin (RASKIN) telah berjalan selama 19 tahun, namun masih banyak kendala dan kelemahan dalam penerapannya. Desa Maccile merupakan salah satu daerah yang ada di kabupaten Soppeng, dimana penyaluran bantuan penerima beras miskin (RASKIN) masih menemui masalah seperti proses seleksi penerimaan bantuan dilakukan secara subyektif oleh pemerintah setempat dengan berdasaran data pendapatan keluarga miskin saja tanpa melihat aspek yang lain, proses pengadministrasian masih manual sehingga membutuhkan waktu lama serta penyampaian informasi hanya melalui selebaran informasi yang dipasang di papan informasi desa. Cara seperti ini tentunya tidak efektif dan efisien dalam pengelolaan pemberian bantuan RASKIN. Oleh karena itu dibutuhkan sebuah sistem yang mampu mengelola mulai dari seleksi penerimaan bantuan RASKIN. Dari permasalahan tersebut, maka dikembangkan sistem penunjang keputusan berbasis website. Sistem penunjang keputusan ini tidak menganti peran dari pengambil keputusan tetapi hanya untuk membantu memberikan alternatif atau rekomendasi pilihan dalam pengambilan keputusan. Tujuan dari penelitian ini yaitu 1). mengembangkan Sistem penunjang keputusan yang berbasis Website. 2). Untuk menerapkan metode Graphic Rating Scale (GRS) dalam Sistem penunjang keputusan seleksi penerimaan RASKIN. Untuk mendukung pelaksanaan pengembangan sistem tersebut, metode yang digunakan adalah Graphic Rating Scale (GRS) untuk perhitungan nilai berdasarkan kriteria penerima RASKIN yang telah ditentukan. Dari hasil penelitian yang telah dilakukan, sistem yang dibuat berjalan sesuai dengan yang diinginkan dan metode Graphic Rating Scale (GRS) memberikan hasil perhitungan penilaian dengan baik serta dapat meberikan perangkingan sehingga dapat memberikan rekomendasi penerima bantuan RASKIN dengan objektif dan transparan.
\end{abstract}

Kata Kunci:, Graphic Rating Scale, RASKIN, Seleksi Penerima.

\begin{abstract}
The Poor Rice Assistance Program (RASKIN) has been running for 19 years, but there are still many obstacles and weaknesses in its implementation. Maccile Village is one of the areas in Soppeng district, where the distribution of aid for poor rice recipients (RASKIN) still faces problems such as the selection process for receiving aid is carried out subjectively by the local government based on income data for poor families only without seeing other aspects, the administration process. it is still manual, so it takes a long time and the delivery of information is only through information leaflets posted on the village information board.
\end{abstract}


Therefore we need a system that is able to manage from the selection to the receipt of RASKIN assistance. Decision support system does not replace the role of the decision maker but only to help provide alternatives in decision making. The objectives of this study are 1). develop Website-based decision support systems. 2). To apply the Graphic Rating Scale (GRS) method in the support system for the selection decision RASKIN acceptance. To support the implementation of the system development, the method used is the GRS for calculating the value based on the criteria for RASKIN recipients that have been determined. From the results of the research that has been carried out, the system is made to run as desired and the GRS method provides good calculation results and can provide a ranking so that it can provide recommendations for recipients of RASKIN assistance objectively and transparently.

Keywords: Graphic Rating Scale, RASKIN, Receiver Selection.

\section{PENDAHULUAN}

Kemiskinan adalah salah satu masalah yang ada di Indonesia. Kemiskinan merupakan kondisi dimana setiap orang atau sekelompok orang yang tidak mampu memenuhi kebutuhan dasarnya untuk mempertahankan dan mengembangkan kehidupan yang lebih baik. Jumlah penduduk miskin di Indonesia pada maret 2019 sebanyak 25,14 juta orang atau sebesar 9,41 persen. Kondisi seperti itu pemerintah masih membuat suatu program guna membantu meningkatkan kesejahteraan masyarakat. Salah satu program pemerintah yang masih dirasakan sama masyarakat sampai hari ini adalah program bantuan Beras Miskin (RASKIN).

Beras Miskin (Raskin) merupakan subsidi pangan dalam bentuk beras yangdiperuntukkan bagi rumah tangga berpenghasilan rendah sebagai upaya dari pemerintah untuk meningkatkan ketahanan pangan dan memberikan perlindungan sosial pada rumah tangga sasaran. Tujuan Program RASKIN untuk mengurangi beban pengeluaran rumah tangga sasaran dalam memenuhi kebutuhan pangan pokok dalam bentuk beras. Program
Raskin telah berjalan selama 19 tahun, namun masih banyak kendala dan kelemahan dalam penerapannya. Keberhasilan Program Raskin diukur dari tingkat pencapaian indikator 6T, yaitu tepat sasaran,tepat jumlah, tepat harga, tepat waktu, tepat kualitas,dan tepat administrasi.

Desa Maccile merupakan salah satu daerah yang ada di kecamatan Lalabata kabupaten Soppeng, dimana penyaluran bantuan penerima beras miskin (RASKIN) masih menemui masalah seperti proses seleksi penerima bantuan Raskin yang dilakukan dengan hanya mendata keluarga dari segi pendapatan saja tanpa melihat aspek yang lain, proses penentuannya dilakukan secara subyektif oleh pemerintah setempat serta dasar pengambilan keputusan tidak transparan, proses pengadministrasian masih manual sehingga membutuhkan waktu lama serta penyampaian informasi hanya melalui selebaran informasi yang dipasang di papan informasi desa. Cara seperti ini tentunya tidak efektif dan efisien dalam pengelolaan pemberian bantuan RASKIN. Oleh karena itu dibutuhkan sebuah sistem yang mampu 
mengelola mulai dari seleksi penerimaan bantuan RASKIN, Proses pengadministrasian yang berbasis komputer, serta penyampaian informasi secara elektornik agar mudah dijangkau oleh masyarakat sasaran.

Untuk mengatasi permasalahan diatas, akan dikembangkan sistem penunjang keputusan berbasis website. Sistem penunjang keputusan yang akan dikembangkan tidak mengganti peran dari pengambil keputusan tetapi hanya untuk membantu memberikan rekomendasi pilihan dalam pengambilan keputusan. Melalui penelitian ini, diusulkan Sistem penunjang keputusan Seleksi Penerimaan Bantuan RASKIN menggunakan metode Graphic Rating Scale (GRS). Pemilihan metode GRS dimaksudkan untuk memberikan kemudahan dalam pengukuran dan perhitungan nilai kriteria. Sistem ini dibangun untuk membantu pengambil keputusan dalam menentukan penerima RASKIN yang sesuai dengan kriteria penilaian administrasi dan informasi raskin dapat juga dipublikasikan melalui Sistem ini sehinnga informasi dapat tersampaikan dengan cepat dan pengelolaan administrasi lebih transparan.

\section{LANDASAN TEORI}

2.1 Sistem Pendukung Keputusan

Decision Support System (DSS) merupakan sistem informasi interaktif yang menyediakan informasi, pemodelan dan pemanipulasian data (Safri Aprudi, 2016). Sistem pendukung keputusan sebagai Sistem Berbasis Komputer Interaktif, yang Membantu para pengambil keputusan untuk menggunakan data dan berbagai model untuk Memecahkan masalah- masalah yang tidak terstruktur (Reza salmon baliara, 2018). Sistem pendukung keputusan merupakan sistem informasi pada level manajemen dari suatu organisasi yang mengkombinasikan data dan model analisis canggih atau peralatan data analisis untuk mendukung pengambilan keputusan yang semi terstruktur dan tidak terstruktur (Iswandy Eka, 2015). Dari pengertian diatas dapat disimpulkan sistem pendukung keputusan adalah sistem yang berbasis komputer yang mengelola data untuk memecahkan masalah yang menghasilkan informasi rekomendasi keputusan.

\subsection{Program Beras Miskin (RASKIN)}

Program RASKIN adalah Program Bantuan beras yang di berikan oleh pemerintah dalam upaya memberikan perlindungan kepada keluarga miskin atau rawan pangan melalui pendistribusian bahan pangan pokok (beras). Program raskin ini merupakan salah satu program pemerintah dalam rangka untuk mensejahterakan masyarakat miskin (Lazarus ramandey, 2017). Usaha kesejahteraan sosial ini dibutuhkan karena pada berbagai negara terdapat warga negara masyarakat yang mempunyai kebutuhan dan masalah di luar kemampuan mereka untuk mengatasinya. Berdasarkan surat keputusan 1241/Menkes/SK/XI/2004 Pasal 1 ayat 1 bahwa, program beras miskin merupakan program pemerintah dalam upaya meningkatkan ketahanan pangan dan memberikan perlindungan kepada keluarga miskin melalui pendistribusian beras dalam jumlah dan harga tertentu.

\subsection{Metode Graphic Rating Scale (GRS)}

Metode GRS adalah metode penilaian yang membagi lima kategori penilaian untuk setiap factor penilaian, faktor yang 
dijadikan penilaian harus terukur agar penilaian dapat dilakukan secara objektif. GRS adalah skala yang digunakan untuk memberikan nilai (Rating) ke suatu variabel (Satria dkk, 2017). Penilai memvalidasi data berbagai dimensi atau kriteria. Penilai menggunakan skala berupa angka-angka mulai dari rendah sampai tinggi. Dalam menggunakan Metode Graphic Rating Scale (GRS) ada beberapa tahap yang harus dilakukan Menentukan kriteria apa saja yang akan dinilai dan bobotnya, Menentukan subkriteria, Menentukan bobot jenis penilai, Menentukan penilai dan keluarga miskin yang akan dinilai (Harni M. Wahyuning dkk ,2015).

Terdapat beberapa alasan mengapa metode ini banyak dipakai secara luas, yaitu :

1. Skala penilaian grafik mudah digunakan

2. Metode ini juga mudah dibuat dan mudah dimodifikasikan jika dibutuhkan.

Dalam menggunakan metode Graphic Rating Scale (GRS) ada beberapa tahap yang harus dilakukan, yaitu :

1. Menentukan kriteria apa saja yang akan dinilai dan bobotnya

2. Menentukan subkriteria

3. Menentukan bobot jenis penilai

4. Menentukan periode penilaian

Perhitungan skor untuk setiap alternatif dalam metode Graphic Rating Scale (GRS) adalah sebagai berikut :

$N K=\sum($ Nilai Sub Kriteria $*$ Bobot $)$

Keterangan :

a) $\mathrm{NK}=$ total nilai dari subkriteria dan bobot b) Nilai subkriteria $=$ nilai subkriteria dari kriteria pada bobot

c) Bobot $=$ tingkat kepentingan (bobot) kriteria

Untuk hasil penilaian akhir menggunakan rumus sebagai berikut :

$$
N A \text { Penilaian }=\sum(N K: \text { Jml. Kriteria })
$$

Keterangan :

a) $\mathrm{N}$ A Penilaian = total nilai dari criteria

b) $\mathrm{NK}=$ nilai dari criteria

c) Jml. Kriteria $=$ jumlah dari kriteria yang dinilai

\section{METODE PENELITIAN}

3.1 Teknik Pengumpulan Data

a. Observasi

Dengan melakukan pengamatan langsung pada kantor desa maccile Kecamatan Lalabata Kabupaten soppeng. Dari hasil observasi peneliti dapat memperoleh datadata yang nantinya akan menjadi referensi baik dalam perancangan dan pembuatan sistem maupun bahan dalam penyusunan laporan penelitian.

b. Wawancara

Dalam pengambilan data pada kantor desa maccile Kecamatan Lalabata Kabupaten soppeng akan dilakukan wawancara kepada kepala desa Maccile menyangkut masalah-masalah dalam pemberia bantuan RASKIN

c. Studi Pustaka

Merupakan metode pengumpulan data dan informasi dengan melakukan kegiatan kepustakaan melalui bukubuku, jurnal penelitian terdahulu dan lain sebagainya yang berkaitan dengan penelitian yang sedang dilakukan.

\subsection{Pemodelan Sistem}

Pada Pemodelan sistem ini akan di gambarkan rancangan dengan model DFD 
(Data Flow Diagram) yang terdiri dari Diagram Konteks, Diagram Level.

a. Diagram Konteks

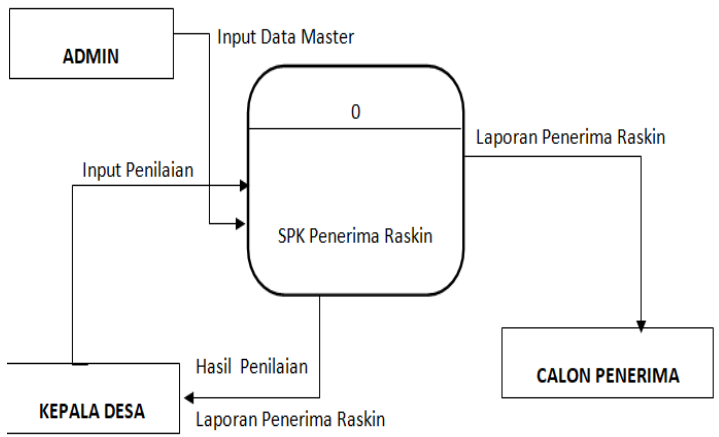

Gambar 2. Diagram Konteks Sistem

Berdasarkan gambar diagram konteks diatas, terdapat tiga entitas yang berhubungan dengan sistem yaitu : Admin, Kepala Desa dan Calon Penerima. Admin menginput data master kedalam Sistem untuk diproses dan menghasilkan database yang nantinya dipakai pada proses selanjutnya. Kepala Desa melakukan input penilaian kedalam sistem. Selanjutnya hasil pemrosesan data oleh sistem menghasilkan output berupa hasil penilaian yang nantinya menjadi dasar pengambilan keputusan serta Laporan Penerima Raskin yang akan diberikan kepada Calon Penerima.

b. Diagram Level

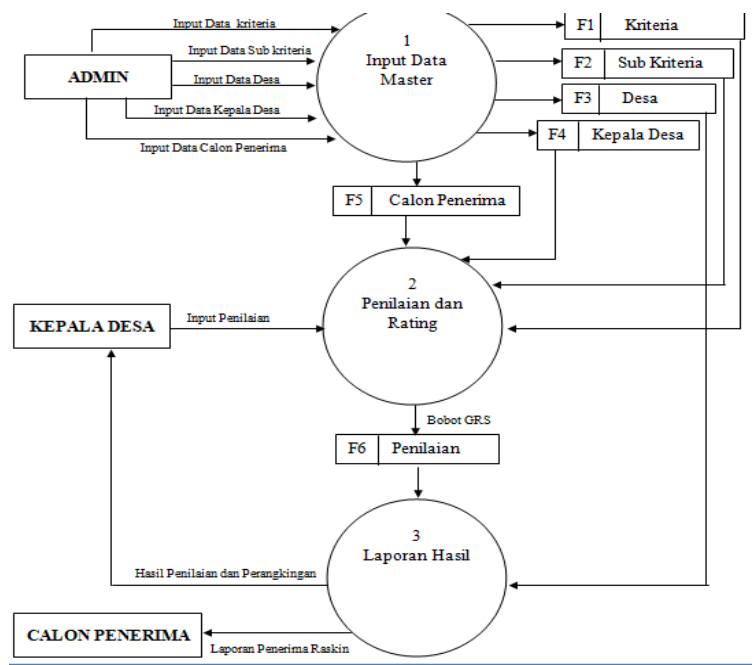

Gambar 3. Diagram Level Sistem
1. Admin menginput data master yang terdiri atas data kriteria, data subkriteria, data desa, data kepala desa dan data calon penerima.

2. Hasil inputan pada data master tersebut selanjutnya menghasilkan simpanan data kriteria, subkriteria, desa, kepala desa dan calonpenerima.

3. Masing-masing simpanan data tersebut selanjutnya diproses pada proses penilaian dan rating untuk selanjutnya dilakukan penghitungan menggunakan metode Graphic Rating Scale.

4. Hasil penghitungan menggunakan metode Graphic Rating Scale selanjutnya menghasilkan simpanan data penilaian.

5. Output yang dihasilkan berupa hasil penilaian dan perangkingan yang akan diberikan kepada kepala desa dan laporan penerima raskin yang akan diberikan kepada calon penerima Raskin.

\section{HASIL DAN PEMBAHASAN}

4.1 Hasil

Setelah melakukan analisis data dan perancangan sistem, selanjutnya dibuat sistem berbasis website untuk penerapan metode Graphic Rating Scale dalam penentuan penerima beras miskin. Berikut hasil implementasi sistem :

a. Implementasi Algoritma

Proses penilaian calon penerima RASKIN dilakukan secara objektif menggunakan metode Graphic Rating Scale. Penilai menggunakan skala berupa angka-angka mulai dari rendah sampai tinggi. pada proses penilaian calon penerima RASKIN di desa Maccile, ada 3 subkriteria yang dinilai berdasarkan urutan prioritas yaitu Penghasilan, Usia dan Tempat Tinggal. Setiap sub kriteria ditentukan nilainya oleh penilai kemudian 
dikalikan berdasarkan bobot masing-masing untuk mendapatkan total nilai dari sub kriteria dan bobot. Total nilai adalah nilai dari kriteria dibagi dengan jumlah kriteria. Adapun implementasi metode graphic rating scale pada proses penilaian calon penerima RASKIN dengan menggunakan bahasa pemrograman PHP dapat dilihat pada gambar dibawah ini.

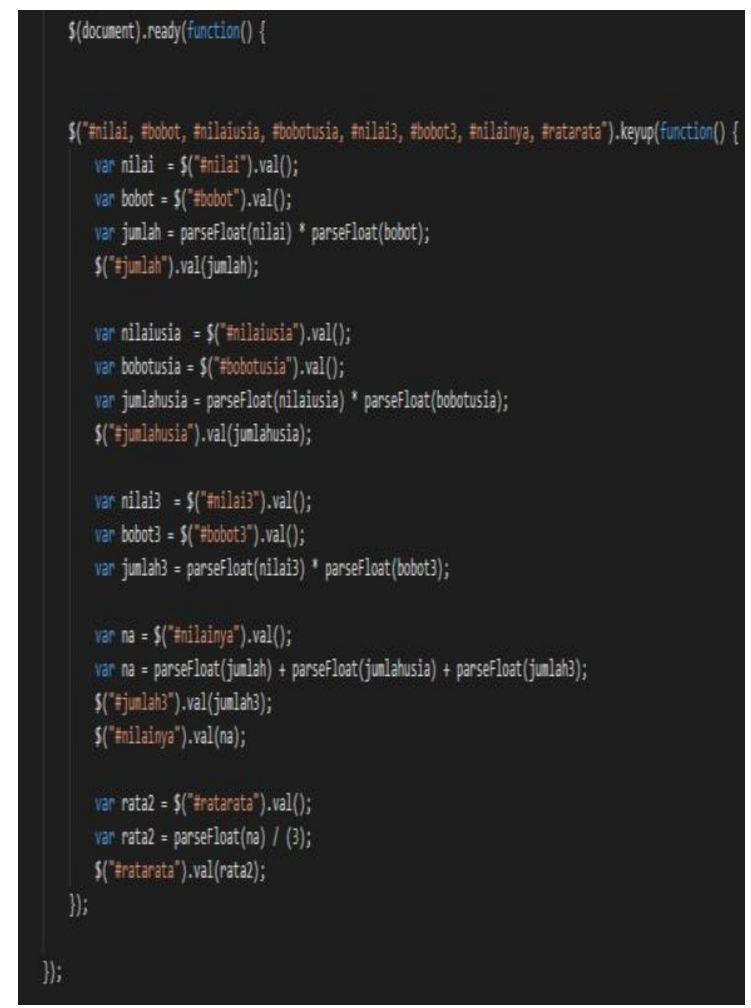

Gambar 4. Implementasi Algoritma GRS pada Aplikasi

Gambar diatas merupakan proses perhitungan Nilai dengan metode GRS. Setiap nilai sub kriteria akan dikalikan dengan bobot kriteria untuk mendapatkan nilai kriteria. Dari masing-masing nilai kriteria yang didapatkan akan dijumlahkan semua nilai kriteria lalu dibagi dengan jumlah kriteria untuk mendapatkan nilai akhir.

b. Implementasi Aplikasi

1) Halaman Beranda

Pada halaman beranda, ditampilkan spesifikasi singkat dari aplikasi sistem pendukung keputusan menggunakan metode Graphic Rating Scale. Selanjutnya user dapat mengklik tombol
Lanjut untuk masuk kehalaman input data master. Halaman beranda dapat dilihat pada gambar dibawah ini :

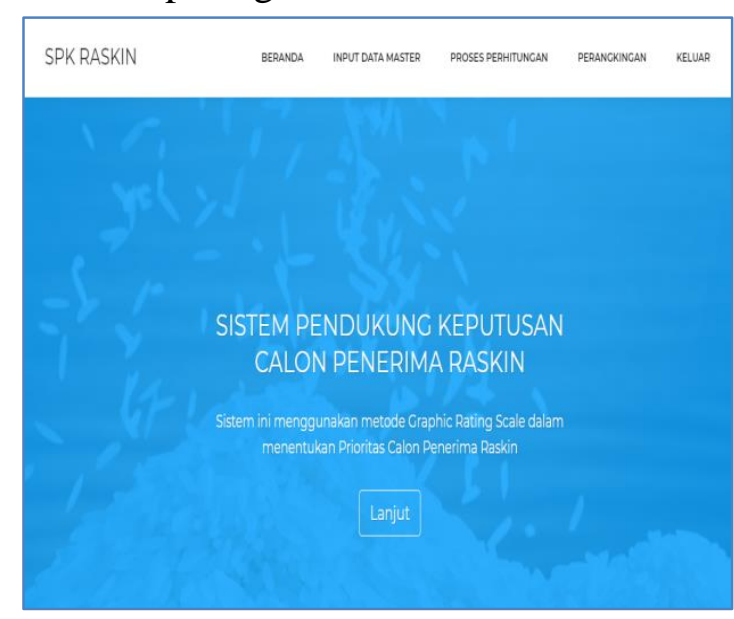

Gambar 5. Halaman Beranda Aplikasi

2) Halaman Input Data Master

Pada halaman input data master terdapat 5 fitur penginputan data yaitu Form input data kriteria untuk menginput data, Form input data sub kriteria untuk menginput data subkriteria, Form input data penilai untuk menginput data penilai calon penerima RASKIN, Form input data calon penerima RASKIN untuk menginput data calon penerima RASKIN, Form input data desa untuk menginput data desa. Adapun tampilan halaman input data master dapat dilihat pada gambar dibawah ini.

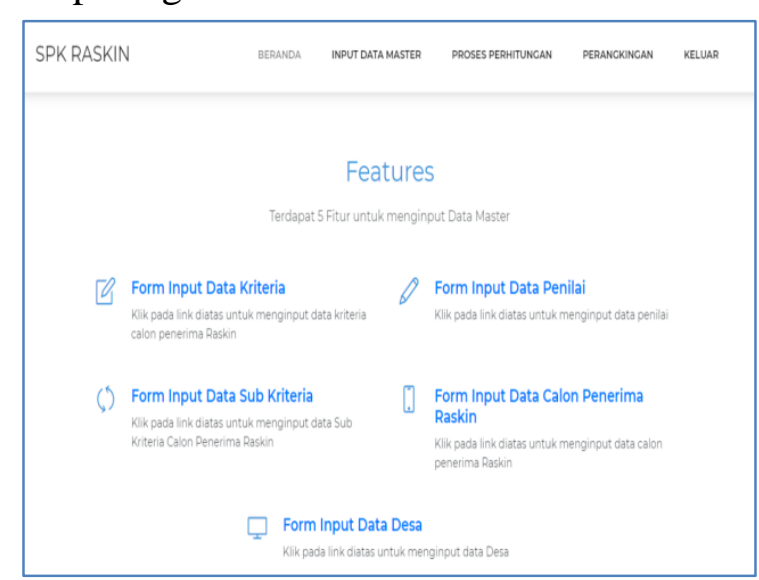

Gambar 6. Halaman Input Data Master 


\section{3) Halaman Input Data Penilaian}

Form in berfungsi untuk menginput data penilaian kriteria calon penerima RASKIN. Sebelum melakukan penilaian, penilai terlebih dahulu menginput NIK calon penerima pada field NIK untuk menampilkan data nama, usia dan penghasilan berdasarkan NIK calon penerima. Setelah data ditemukan, maka proses selanjutnya adalah penilaian kriteria yang terdiridari 3 kriteria yaitu kriteria Penghasilan, Usia dan Tempat Tinggal. Pada penilaian kriteria, penilai memilih opsi sub kriteria terlebih dahulu, setelah memilih salah satu sub kriteria maka data bobot akan ditampilkan pada field Bobot, selanjutnya penilai menginput nilai pada field Nilai untuk menampilkan Total Nilai dari kriteria tersebut. Setelah semua penilaian kriteria telah terpenuhi selanjutnya akan ditampilkan Hasil Penilaian pada field Nilai Keseluruhan dan Nilai Akhir. Untuk menyimpan data maka penilai harus mengklik tombol Simpan. Untuk mengosongkan nilai pada semua field, maka klik tombol Kosongkan. Untuk melihat data yang telah tersimpan, klik tombol Lihat Data. Adapun tampilan form input penilaian calonpenerima RASKIN dapat dilihat pada gambar dibawah ini :

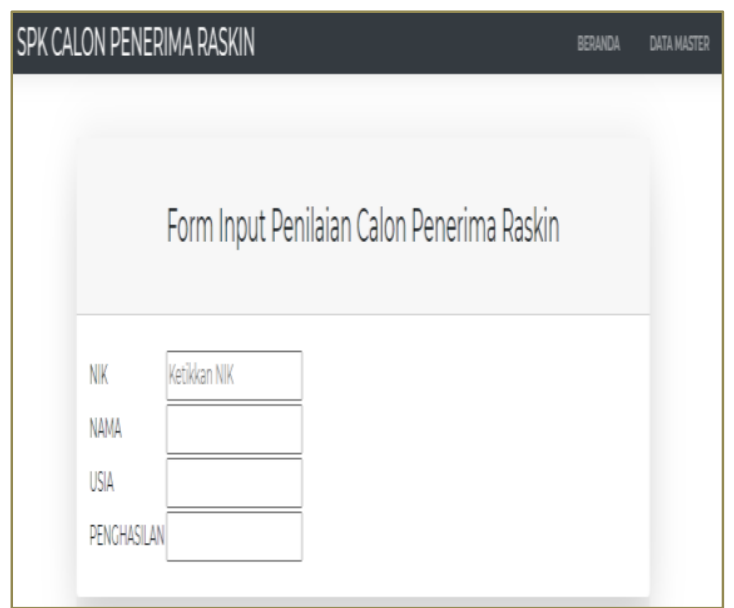

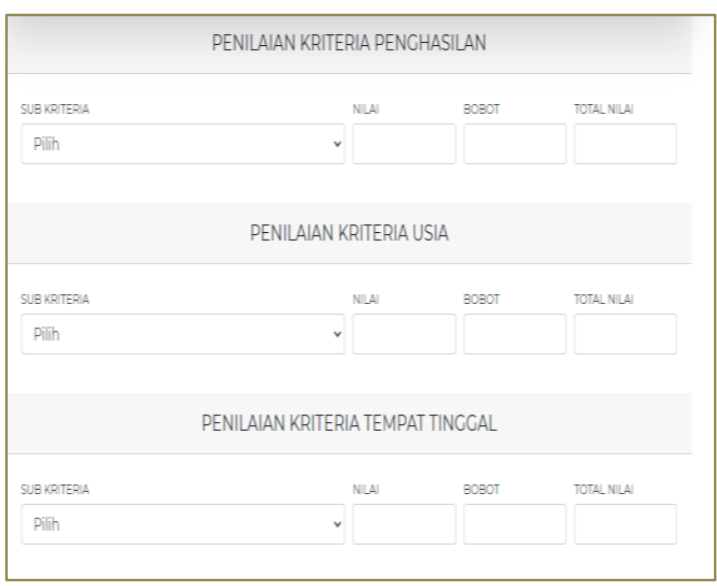

Gambar 7. Halaman Proses Penilaian

4) Halaman Perangkinan Hasil Penilaian telah proses penilaian selesai, seluruh data calon penerima raskin yang telah dinilai disimpan pada tabel data penilaian. Selanjutnya hasil penilaian tersebut akan dilakukan proses sorting berdasarkan nilai tertinggi dari nilai ratarata setiap calon. Nilai yang tertinggi akan ditampilkan secara berurutan dari atas kebawah mulai dari nomor urut 1 dan seterusnya. Adapun halaman perangkingan dapat dilihat pada gambar dibawah ini.

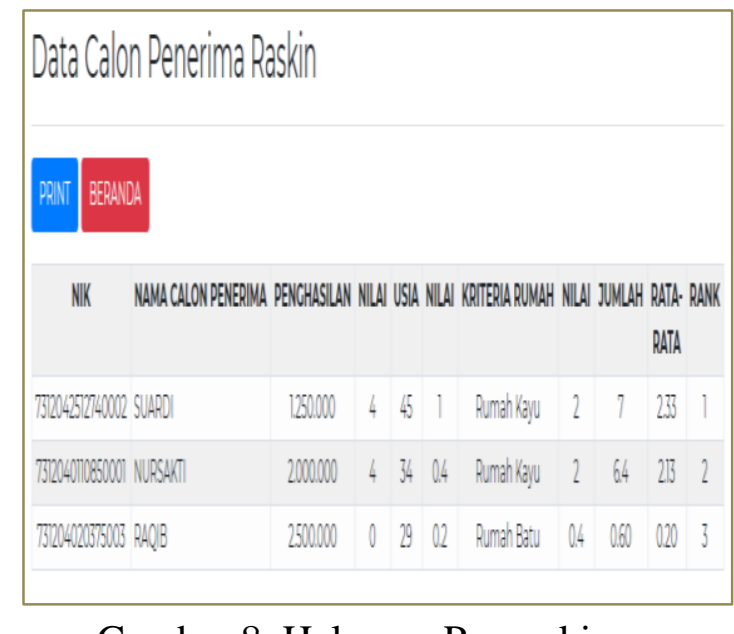

Gambar 8. Halaman Perangkingan

\subsection{Pengujian Sistem}

Pengujian sistem merupakan salah satu bagian yang sangat penting dalam pembangunan sebuah perangkat lunak, 
pengujian ditujukan untuk menemukan kesalahan-kesalahan pada sistem dan memastikan sistem yang dibangun telah sesuai dengan apa yang direncanakan sebelumnya. Pengujian dilakukan untuk menjamin kualitas dan juga mengetahui kelemahan dari perangkat lunak. Tujuan dari pengujian ini adalah untuk menjamin bahwa perangkat lunak yang dibangun memiliki kualitas yang handal, yaitu mampu mempresentasikan kajian pokok dari spesifikasi analisis, perancangan dan pengkodean dari perangkat lunak itu sendiri. Dalam pengujian ini digunakan model pengujian blackbox dan akan mengambil contoh kasus dari tahap pengujian program terhadap kesesuaian dengan kebutuhan sistem.

a. Pengujian Login Sistem

\begin{tabular}{|l|l|l|l|}
\hline $\begin{array}{c}\text { Data } \\
\text { masuk }\end{array}$ & $\begin{array}{c}\text { Yang } \\
\text { diharapkan }\end{array}$ & Pengamatan & $\begin{array}{l}\text { Kesim } \\
\text { pulan }\end{array}$ \\
\hline Login & $\begin{array}{l}\text { Tidak dapat } \\
\text { login jika } \\
\text { password } \\
\text { atau user } \\
\text { name salah. }\end{array}$ & $\begin{array}{l}\text { Muncul } \\
\text { pesan } \\
\text { "Maaf } \\
\text { Username } \\
\text { dan } \\
\text { Password } \\
\text { anda salah" }\end{array}$ & Sesuai \\
\hline \multirow{4}{|c|}{ Screen Shoot } \\
\hline
\end{tabular}

b. Pengujian Halaman Calon Penerima Raskin

\begin{tabular}{|c|c|c|c|}
\hline $\begin{array}{l}\text { Data } \\
\text { masuk }\end{array}$ & $\begin{array}{l}\text { Yang } \\
\text { diharapkan }\end{array}$ & Pengamatan & Kesimpulan \\
\hline Simpan & $\begin{array}{l}\text { Tidak } \\
\text { dapat } \\
\text { menyimp } \\
\text { an data } \\
\text { ketika } \\
\text { belum } \\
\text { ada } \\
\text { inputan } \\
\text { data }\end{array}$ & $\begin{array}{l}\text { Field } \\
\text { Tidak } \\
\text { Boleh } \\
\text { Kosong }\end{array}$ & Sesuai \\
\hline \multicolumn{4}{|c|}{ Screen Shoot } \\
\hline 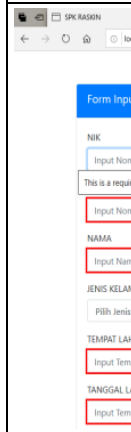 & SP & PK RASKIN & 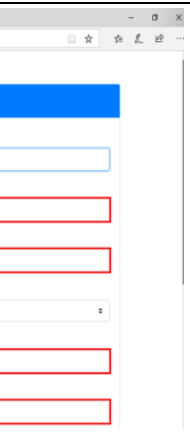 \\
\hline
\end{tabular}

\section{SIMPULAN DAN SARAN}

Berdasarkan hasil penelitian yang telah dilakukan, maka dapat ditarik kesimpulan sebagai berikut :

a. Aplikasi yang dibangun telah sesuai dengan hasil rancangan berdasarkan data hasil wawancara dimana proses seleksi penerimaan RASKIN dilakukan dengan tiga variable kriteria yaitu penghasilan, usia, dan tempat tinggal

b. Hasil implementasi metode graphic rating scale dapat meberikan perhitungan nilai berdasarkan kriteria yang digunakan dan dapat melakukan perangkingan berdasarkan hasil penilaian. 


\section{UCAPAN TERIMA KASIH}

Pada proses penelitian ini tidak terlepas dari beberapa pihak yang meberikan konstribusi sehingga penelitian ini dapat dilaksanakan dan diselesaiakan dengan baik. Oleh karena itu ucapan terimakasih disampaikan kepada:

a. Ketua STMIK Lamappapoleonro Soppeng yang telah memberikan dukungan penuh kepada peneliti.

b. Ketua LP3M

STMIK Lamappapoleonro yang telah memberikan persetujuan untuk melaksanakan penelitian ini.

c. Pemerintah dalam hal ini kementerian Riset, Teknologi, dan Pendidikan Tinggi yang telah meberikan bantuan hibah penelitian.

\section{DAFTAR PUSTAKA}

Harni Mukti Wahyuning dkk (2015). Sistem pendukung keputusan mutasi anggota kepolisian polresta palembang dengan Menggunakan metode graphic rating scale. Jurnal Sistem Informasi, Universitas Bina Darma,Palembang, 2015.

Iswandy Eka, (2015). Sistem penunjang keputusan untuk menentukan penerimaan dana santunan sosial anak nagari dan penyalurannya bagi mahasiswa dan pelajar kurang mampu di kenagarian barung barung balantai timur, jurnal teknoif, vol. 3 no. 2 oktober 2015 .

Lazarus ramandey, (2017). Dampak sosial program pembagian beras miskin (RASKIN) di kampung amar distrik amar kabupaten mimika. Universitas cenderawasih. 2017.

Masitah Handayani, (2017). Sistem pendukung keputusan penentuan penerimaan RASKIN menggunakan metode TOPSIS. Jurnal teknologi informasi (JURTI) volume 1, nomor 1 , juli 2017.

Reza salmon baliara, (2018). Sistem pendukung keputusan calon penerima raskin dengan metode polygons area method (PAM) di kelurahan airnona kota kupang. Jicon, vol. 6 no. 2, oktober 2018.

Safri Aprudi, (2016). Sistem pendukung keputusan seleksi penerima beras untuk Keluarga miskin (raskin) pada kelurahan tanah periuk Kecamatan lubuklinggau selatan II kota lubuklinggau Menggunakan metode analithycal hirarchy process $(A H P)$. JTI, Vol 8 No.1, Juni 2016.

Satria dkk, (2017). Penerapan metode graphic rating scale (grs) dalam Penilaian kinerja karyawan. Jurnal kilat vol. 6 no. 2, oktober 2017. 